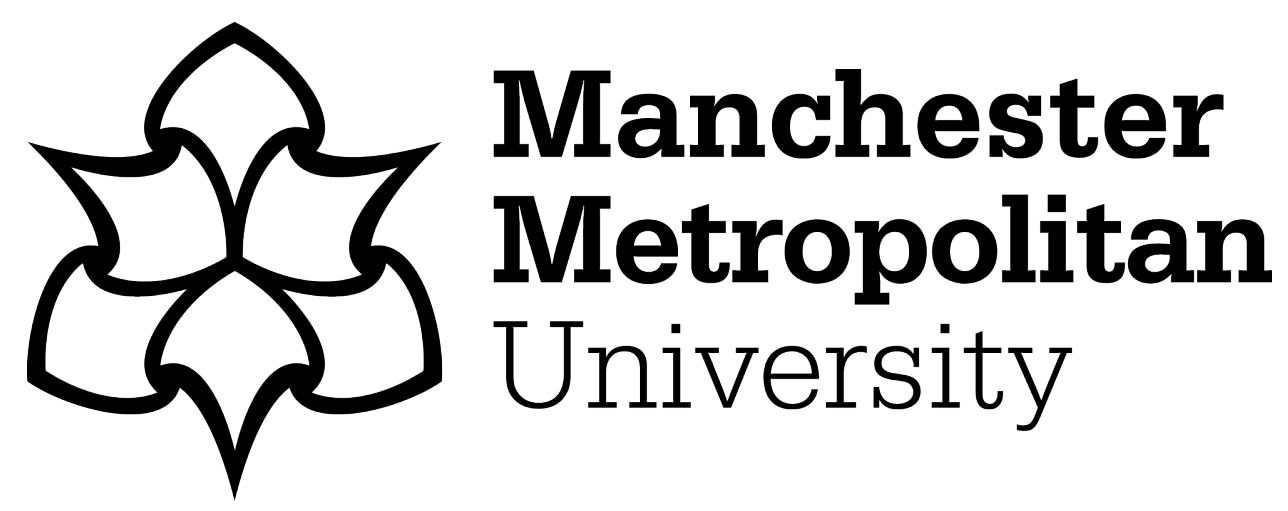

Herrero, Carmen and Escobar, M (2018) A Pedagogical Model for Integrating Film Education and Audio Description in Foreign Language Acquisition. Translation and Translanguaging in Multilingual Contexts, 4 (1). pp. 30-54. ISSN 2352-1805

Downloaded from: https://e-space.mmu.ac.uk/619833/

Version: Accepted Version

Publisher: John Benjamins Publishing Company

DOI: https://doi.org/10.1075/ttmc.00003.her

Please cite the published version 
Article to be published in the journal Translation and Tranlanguaging in Multilingual Contexts 4:1 (2018)

\title{
A Pedagogical Model for Integrating Film Education and Audio Description in Foreign Language Acquisition
}

\author{
Carmen Herrero and Manuela Escobar \\ Manchester Metropolitan University / Universidad de Sevilla
}

Films are particularly powerful pedagogical tools that can help improve the linguistic skills of foreign language learners. Audio describing tasks can provide additional benefits. However, for an efficient use of feature films, learners need to be trained on how to elaborate audio description texts and develop active viewing strategies. This article discusses a language teaching approach that advocates the addition of Film Literacy education and audio description tasks to the language curriculum. It focuses on the application of audio description, in both oral and written form, to the acquisition of Spanish as a foreign language in Higher Education. It presents a pedagogical model designed to help students develop linguistic, cultural and intercultural competences while encouraging the aesthetic appreciation of films as cultural objects that can be evaluated through a wide range of critical approaches. 
Keywords: Film Literacy, Audio Description, Language Acquisition, Pedagogy

\section{Introduction}

Audiovisual material is a powerful pedagogical tool widely used to improve the linguistic skills of Foreign Language (FL) learners. In the last decade in particular it has been profitably employed to incorporate audiovisual translation tasks in FL teaching and, more recently, Audio Description (AD) tasks have also been exploited with encouraging results suggesting that they can help improve the linguistic skills of FL learners. However, for an efficient use of feature films in language teaching, learners would benefit from training on how to elaborate $\mathrm{AD}$ texts and develop active viewing strategies. This article discusses a language teaching approach that advocates the addition of education in Film Literacy and AD tasks to the language curriculum. ${ }^{\mathrm{i}}$ It focuses on the application of $\mathrm{AD}$, in both oral and written form, to the acquisition of Spanish as a FL in Higher Education (HE). It presents a pedagogical model designed to help students develop linguistic, cultural and intercultural competences while encouraging the aesthetic appreciation of films as cultural objects that can be evaluated through a wide range of critical approaches. In the first section we begin by offering a brief analysis of the different approaches to teaching and learning a FL on which our proposal is based. The pedagogical model, which we started to develop over a decade ago, supports the principle that working 
with multimodal texts can address the educational needs of intercultural awareness and film Literacy, adding a new nuance to the notion of Content and Language Integrated Learning (CLIL). Considering films as multimodal texts, the model leads students to pay attention to the multiple modes of meaning and how they interact to render a comprehensive linguistic, social, cultural, and intercultural description.

In the second section, we argue that Film Literacy is a type of literacy that has often been overlooked in the language curricula of institutional education at both Secondary and Higher levels. We suggest that applying the three key dimensions of film education - Creative, Critical and Cultural - (British Film Institute 2008; 2010a; 2010b; 2013) to AD tasks improves motivation and aids the language learning process. After a brief overview of the use of audiovisual texts for language learning and teaching and the application of audiovisual translation to foreign language acquisition, this second part focuses on a pedagogical approach based on the integration of $\mathrm{AD}$ and Film Literacy education. We suggest that, by integrating $\mathrm{AD}$ as part of the FL curriculum, learners benefit from the acquisition of a wide range of tools and skills and develop "film sensibility" (BFI 2013, online). Furthermore, language learning and film education activities equip learners with crucial transferrable skills (creativity, critical thinking and cultural/intercultural awareness) that are highly valued by employers. These activities can potentially contribute to lifelong learning by 
making learners competent and skilled users of media as well as information and communication technologies.

\section{Methodological foundation: a literature review of the principles}

The framework presented in this study integrates different approaches to teaching and learning a FL. First, it is grounded in the concept of communicative competence (Canale and Swain 1980), further developed into the concepts of grammatical, discourse, sociolinguistic and strategic competences (Canale 1983) and interactional competence (Celce-Murcia 1995; Celce-Murcia et al. 1995). It partially adapts the task-based learning (TBL) theory that proposes the acquisition of a foreign language based on tasks (Nunan 1989), with emphasis on 'transferable skills' (Holmes 1995) and learning by doing. ${ }^{\text {ii }}$ It follows the principles of Project-Based Learning (PBL), that include authentic content and cooperative learning (Thomas 2000). Three of the critical concerns for PBL are integrating technology, assessment (computer or physical models, videos, games, writing samples, plays or exhibits) and scaffolding the learning process. A central goal of this theoretical approach is to foster students' acquisition of $21^{\text {st }}$ century competences (Condliffe et al. 2016, 37). This pedagogical proposal is also grounded in the literacy-based approaches guiding some of the predominant

curricular and pedagogical reforms directing current FL teaching (Kern 2003; Paesani et al. 2016). The following sections provide a brief summary of these approaches before outlining some research results that have 
contributed to expanding the use and value of audiovisual media in FL instruction.

\subsection{Literacy-based approaches and multimodality}

The overall shift brought by the rapid expansion of the Internet and the wide range of practices linked to the new information and communication technologies (ICTs) has shaped the term literacy into a broader and multiple concept. To capture the complexity and changing nature of the term literacy, Leu et al. (2013) opt for a multiple theoretical perspective divided into two levels: lowercase (new literacies) and uppercase (New Literacies). Lowercase theories include those that focus on a specific discipline or area of new literacy and new technology. New Literacies looks at the common elements across the theoretical research and practices of the lower literacies. One of the central principles of New Literacies is that they are "multiple, multimodal, and multifaceted" (Leu et al. 2013, 1158). Within this context, the term 'multiliteracies' was coined by the New London Group to account for the rapid changes in the concept of literacy, due to globalization, technology and increasing linguistic, cultural and social diversity. ${ }^{\text {iii }}$ Their seminal work, "A Pedagogy of Multiliteracies: Designing Social Futures”, proposes that literacy "now must account for the burgeoning variety of text forms associated with information and multimedia technologies" $(1996,61)$.

Multimodality is another common principle related to New Literacies. Indeed, since the development of Web 2.0 and given the ever increasing role of visual information in the digital age, communication is increasingly 
based on multimodal texts, which can be defined as "texts that communicate their message using more than one semiotic mode, or channel of communication" (Openlearn 2010, online). Challenging the traditional view of the dominant role of written texts in teaching and learning, Gunther Kress and Theo van Leeuwen (2001) argued that other modes of communication (such as image, gesture, music, spatial and bodily codes) could also contribute to the multimodal ways of meaning-making and knowledge construction. They identify five design elements in the meaning-making process represented in Figure 1: Linguistic, Visual, Audio, Gestural and Spatial meaning. The multimodal patterns of meaning are combinations of the above semiotic codes.

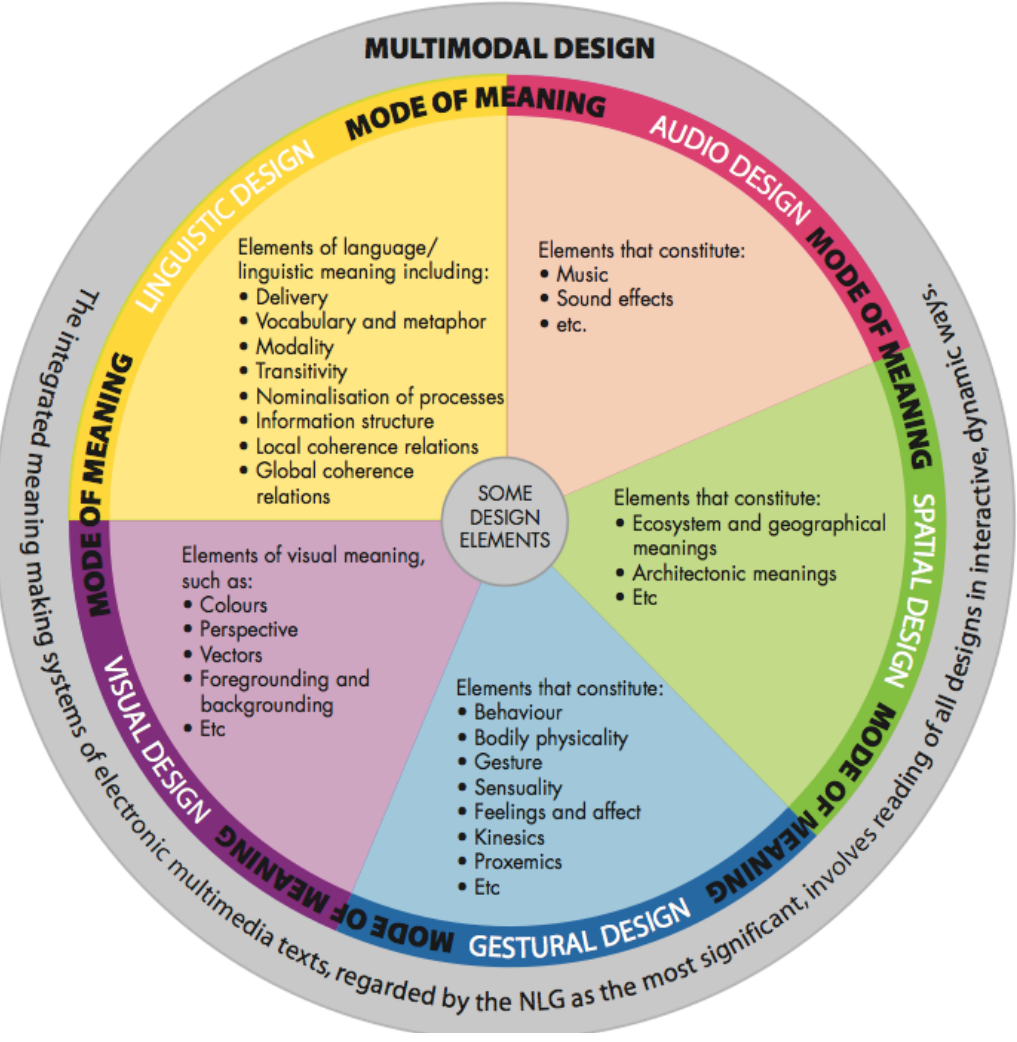


Figure 1. Diagram by Cope and Kalantzis (2000), redesigned by decafnomilk.com in Chan and Herrero (2010) Therefore, multimodal literacies refer to the meaning-making that takes place when interacting with and producing multimodal texts. It focuses on the 'modal affordances' and the orchestration and interaction of semiotic resources or modes (language, images, gesture, etc.) in different modalities (visual, aural, haptic, olfactory, and gustatory) during the design of multimodal texts or genres (blogs, posters, websites, films, etc.) (Kress 2010). Kress (2003) noted the cultural, social and discourse values carried by multimodal texts. Unsurprisingly, educators and researchers are calling for multiple multimodal text exposures in FL, including its use as instructional tools and in creative projects (Chan and Herrero 2010; Baños and Sokoli 2015; Paesani et al. 2016). However, research on the use of multimodal texts in FL settings reveals that, although language learners "develop awareness and understanding of the synesthetic relationship between multimodal resources for making meaning", they do not take "full advantage of the meaning potential of these new modalities" (Paesani et al. 2016, 242). There is no doubt that the impact of audiovisual media on citizens' lives makes the acquisition of critical and creative competences through effective film and Media Literacy teaching more relevant (Wilson et al. 2011). However, it is not an area that has been explored thoroughly in the language classroom (FILTA 2010; Thaler 2014; Herrero 2016).

Another level of multiplicity refers to the new social practices and 
skills necessary to interact online with information and individuals from different social and cultural backgrounds. Therefore, the need for developing intercultural understanding becomes a key issue in any educational model (Byram et al. 2013; Dervin and Liddicoat 2013); and it is recognised as a fundamental soft skill in the literature relevant to the employment prospects of HE graduates (Jones 2013; British Academy 2016). Nevertheless, as noted by Pegrum (2008), Herrero (2009) and Barrett et al. (2014), films are still an under-exploited resource for promoting intercultural competence and developing learners' critical thinking skills.

The practices for new literacies require a very different set of values, priorities and attitudes. The advances in ICT encourage participatory and collaborative practices and sharing with others, giving more value to the distribution of information and knowledge than to the recognition of authorship (Lankshear and Knobel 2003). Henry Jenkins (2008) uses the term participatory culture to explain the growth of user-generated content, 'distributed cognition' and 'collective intelligence'. This new ethos is gradually permeating the development of new literacy strategies in education (Jenkins et al. 2009).

The pedagogical model presented in this article is based on the aforementioned methodological principles. In particular, it takes into account the changes in the concept of the term literacy due to the new social, cultural and technological practices, and captures the paramount 
importance of multimodal communication and Media Literacy in FL learning and teaching.

2.2. The use of audiovisual texts for language learning and teaching

Audiovisual media allow for the simultaneous reception of both audio and visual input information, i.e., watching television, videos or films with subtitles. Teachers and researchers have valued audiovisual texts as a resource for improving different areas of linguistic competence for over two decades. Herron (1994) showed in a comparative study - video versus text materials - carried out among university students in France, that the use of video improves listening comprehension capacity. Weyers (1999) confirmed a similar hypothesis applied to Spanish as FL through the use of soap operas for several months as part of a guided and structured task inserted into the curriculum. The results confirmed, at the same time, an improvement in the quantity and quality of oral production of students exposed to the audiovisual task. Other researchers have corroborated this (Chapple and Curtis 2000, among others).

Focusing on language acquisition and more specifically on oral and aural skills, audiovisual texts are generally used to offer students access to a wide range of voices and accents from different geographical areas. They expose FL learners to linguistic varieties (geographical, social, diachronic, situational) as well as to different jargon. Finally creative tasks and presentations using audiovisual material can help to refine intonation and pronunciation (Baddock 1996; Porcel 2009). 
Many studies argue in favour of the exploitation of video, films, television and ads as tools to appreciate and practice a variety of grammar structures (Altman 1989; Ruiz Fajardo 1994; Cardillo 1996). As Toro Escudero states (2009) the diversity of linguistic registers in films illustrates how learning grammar should be related to understanding the syntax of language in use rather than learning the rules of a prescriptive grammar.

In relation to semantics, audiovisual texts contribute to a contextualised learning of vocabulary and the visualisation of meaning (Canning-Wilson 2000). Furthermore, its use helps students with incidental learning of vocabulary and particularly of lexical units and their cultural contexts, such as formulae, collocations and idioms (Argüelles-Díaz 2015). In fact, because of their format, short films and ads are especially useful for a controlled experience of lexical units in context (Guerra Robles 2013; Argüelles-Díaz 2015). Furthermore, the amount of vocabulary necessary to be able to follow a film or television programme in FL should be considered. The recommendations inferred from Webb and Rodgers' study (2009) for incidental vocabulary acquisition could be applied to the learning of any FL: pre-viewing activities, the use of subtitles in FL and an increase in the frequency of contact with new words through regular work with films.

Other studies argue that learning is improved when some preliminary information is introduced (advance organiser) to facilitate audiovisual comprehension and lighten cognitive load before the viewing. The use of 
descriptions and images, presentation of vocabulary and short questions to guide the learner are some of the recommendations provided by various researchers (Herron et al. 1995; Chung and Huang 1998; Lin and Chen 2006).

Given the interrelation between language and culture, it is advisable to integrate a cultural component in teaching FL. As authentic material, ${ }^{\text {iv }}$ audiovisual texts are a tool that can increase learners' motivation (Sherman 2003) and also help to develop sociocultural competence because they facilitate the understanding of communicative behaviour (Corpas Viñals 2000).

Audiovisual texts give the opportunity to observe different registers, formal, informal, academic, etc. (Pérez Basanta 1999; Brandimonte 2003; Meler 2005). They help to contextualise language in use and are therefore ideal for widening comprehension and production of pragmatic meaning, paying attention to both linguistic and social elements and their context (Bustos Gisbert 1997; Corpas Viñals 2000; Vílchez Tallón 2007). It is worth noticing that through the use of videos, and especially films, FL students are exposed to items that could otherwise be difficult to show, such as body language and expressions associated with a specific culture, paralinguistic elements and sublinguistic sounds (Altman 1989; Herrero 2009; Chan and Herrero 2010). Ultimately, audiovisual texts in the FL classroom are ideal tools for supporting an 'effective and affective learning' across a wide range 
of areas (linguistic, socio-pragmatic and cultural competences) (Crespo Fernández 2012).

\subsection{Audiovisual Translation applied to FL teaching and learning}

A growing area of research in the field of audiovisual media in Applied Linguistics is Audiovisual Translation (AVT): audio description, dubbing, subtitling and voiceover. There is an increasing number of empirical studies that look into the benefits of AVT applied to the teaching and learning of a FL, especially since to the wide availability of IT tools favours a wider use of AVT. Intralinguistic (from oral to written message in the same language) and interlinguistic subtitles (different languages) facilitate vocabulary acquisition, reading comprehension, oral production and motivation (Vanderplank 1988; 2010; Borrás and Lafayette 1994; Guillory 1998; Bird and Williams 2002; Danan, 2004; Caimi 2006; Díaz-Cintas 2012). So far, research on audiovisual media and its application to foreign language acquisition has focused mainly on the use of subtitles for L1 or L2 and their potential for the development of such skills as oral and aural comprehension and lexical acquisition, with subtitles as a bridge between reading and aural comprehension. There is also a more direct application to the improvement of linguistic skills for translation teaching and the training of professional translators (Borrás and Lafayette 1994; Gambier 2007; Sokoli et al. 2011; Díaz-Cintas 2012). There has been significant growth in interest in the use of subtitles for FL teaching purposes (Williams and Thorne 2000; Sokoli 2006; Bravo 2008; Talaván 2010; Borghetti 2011; Incalcaterra McLoughlin 
and Lertola 2011; Talaván 2013; Incalcaterra McLoughlin and Lertola 2014). As pointed out by Talaván $(2010,286)$, "subtitling as a task" (the production of subtitles by students) complements the use of "subtitles as support" helping learners to improve oral comprehension and fostering autonomous learning.

On the other hand, dubbing is valued for its capacity to enhance active participation by students (Danan 2010). Chiu (2012) and SánchezRequena (2016) have used dubbing to improve pronunciation, intonation and fluency in English and Spanish respectively. Navarrete (2013) has shown the advantages of applying dubbing for Spanish learning within the ClipFlair project frame. ${ }^{\vee}$ Talaván and Ávila Cabrera (2015) have stressed the use of dubbing to improve writing and speaking as well as learners' translation skills.

$\mathrm{AD}$ research has analysed mainly linguistic and semantic content in this type of text (Díaz-Cintas 2010), its features as a special type of text and the possibilities of translation (Bourne and Jiménez Hurtado 2007; Orero 2007; Maszerowska et al 2014; Matamala and Orero 2016; Talaván et al. 2016). ${ }^{\mathrm{vi}}$ However, AD is less used for teaching purposes, although it is now starting to be applied with a view to improving vocabulary acquisition, as well as the four linguistic skills (Ibáñez Moreno and Vermeulen, 2014; Talaván and Lertola, 2016).

\section{An inclusive pedagogical proposal}


The literature review previously presented has outlined the theoretical approaches on which we are basing our pedagogical approach for the use of $\mathrm{AD}$ in FL. First, working with film texts boosts students' interest and enhances FL learning skills; secondly, film analysis enables learners to understand that films are complex meaning-making documents. Furthermore, it builds on media practices that learners use outside the formal learning spaces and facilitates a better understanding of the complexity and vital importance of multimodal communication in today's world.

\subsection{Pedagogical approach}

This study focuses on $\mathrm{AD}$ of feature films. $\mathrm{AD}$ is defined as the techniques and skills applied to compensate for the lack of visual input in any message providing appropriate sound information that translates or explains the message to an impaired visual receiver (Díaz-Cintas 2010). However, for this study it is particularly useful to consider $\mathrm{AD}$ as a form of creative writing, a "descriptive narrative" (Greening and Rolph 2007, 127), and a type of text that maintains an "intimate intertextual relation with the filmic text" (Hannelore Poethe 2005, 40, in Bourne and Hurtado 2007, 176).

The pedagogical approach that we are presenting in this section focuses on the audiovisual and written components of AD applied to the teaching of Spanish as a Second/Foreign Language. The principles of the 
model, based on the previously discussed multiliteracies framework, may be stated as follows:

a. The importance of merging language and content in the curriculum.

b. The understanding that a wider range of multimodal texts should be part of the language curriculum.

c. Films are multimodal texts and, therefore, they transmit information through a combination of semiotic systems (image, gesture, music, spatial and bodily codes). They combine what Burn $(2013,2)$ defines as "contributory modes" (movement, lighting, costume, objects, sets, etc.) and "orchestrating modes", filming and editing which are the "overarching framing systems in space and time").

d. Audiovisual text and films in particular are ideal tools for raising students' cultural and intercultural awareness as they allow for reflection on discourse practices as situated discourses (historically and culturally).

e. Film Literacy is an essential competence that language teachers and students should master.

f. AD is a multiliteracy-oriented task that integrates both analytical and creative components (awareness, analysis, reflection and creative language use).

g. AD projects enhance language learners' linguistic, cultural and intercultural competences. They comprise encoding and decoding as fundamental processes for $\mathrm{AD}$ tasks. ${ }^{\mathrm{vii}}$ 


\subsection{Strategies and competences in $\mathrm{AD}$}

A review of the competences of audio describers provides a useful guide for the design of $\mathrm{AD}$ tasks for the language classroom. First, from a linguistic point of view, both academics and professionals agree on the need to summarise information accurately and objectively, in order to adapt the text to the time set between dialogues (Orero 2005); at the same time, there is a need to take into account the audience so that the proper register can be used (Matamala 2006; Matamala and Orero 2007; Vercauteren 2007). Finally, audio describers should possess a wide range of vocabulary, master different linguistic registers, be aware of the consequences of making pragmatic choices, as well as mastering rhetorical devices to convey information, and add texture to the description (Díaz-Cintas 2006; Matamala and Orero 2007). Although professional audio describers are required to develop these skills to a higher level and obtain qualifications, language learners could benefit from being introduced to key professional skills that could lead to postgraduate study in this area; e.g. they should demonstrate grammatical, sociolinguistic, discourse and strategic competences in productive and receptive language skills and mediation, including near-native phonological; grammatical and lexical precision in target language speech, and grammatical and lexical accuracy in target language writing in a wide variety of personal, academic, professional and other domains, and across a full range of genres. ${ }^{\text {viii }}$ 
Film is an art form and a contemporary language. Therefore, aesthetic appreciation of movies should be guided with different critical approaches. All these reasons explain the importance of having activities that contribute to film education in schools and Higher Education. Unsurprisingly, the competence related to the knowledge of film language and the semiotics of image required to be able to provide descriptions that render visual imagery and its impact is of special interest (Orero and Matamala 2007, Orero 2012; Romero Fresco 2013). The AD standards adopted in different countries (UK, Greece, France, Germany, Spain, and the USA) were the starting point for the creation of the AD pedagogical model that we are presenting in this article. These guidelines are broken down into four major components (when, where, who and what) that constitute the essential parts of the description (Rai et al. 2010). According to Vercauteren (2007), in order to elaborate $\mathrm{AD}$ texts, the following questions must be answered: a) what must be described, b) when it must be described, c) how it must be described, d) how much must be described. Before presenting our pedagogical model, we will discuss these four questions in more detail:

a) What must be described? Snyder (2013) suggests starting with the description of the relevant facts and of who is on the screen. The UK Ofcom guidelines on Television Access (2017) includes the description of other relevant elements such as on-screen action or information as well as any sound that may be easily identifiable. In summary, the key is to identify and describe those features that are relevant to the storyline. 
b) When to describe? AD should take place during gaps or silent moments between dialogues.

c) How much to describe? Clark (2007, online), outlining the standard techniques in $\mathrm{AD}$, provides this useful advice: "describe when necessary, but do not necessarily describe."

d) How to describe visual and aural information? A comparative study of AD guidelines in different European countries (Rai et al. 2010) points out two common categories consistently included as consistent in the recommendations: on the one hand, register and style and, on the other, grammar structures. Table 1 provides a summary on how to describe visual and aural information.

Table 1. How to describe visual and aural information based on $\mathrm{AD}$ guidelines from different countries (Rai et al. 2010) 


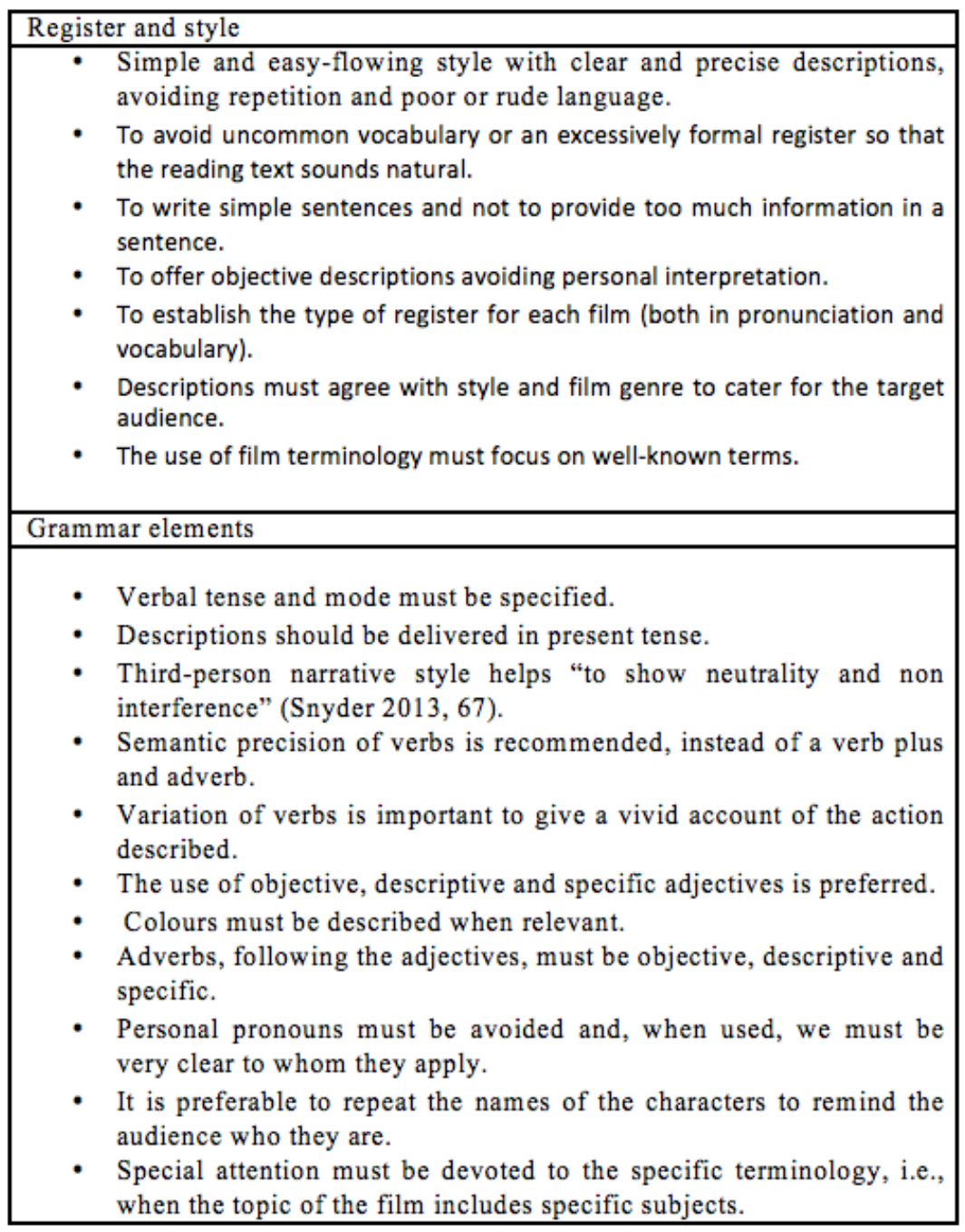

The degree of specialisation of the description is not fixed; in our view, it depends on the target audience. Table 2 summarises the questions and guidelines for elaborating an $\mathrm{AD}$ script.

Table 2. Questions and guidelines for elaborating an AD script

\begin{tabular}{|l|l|l|l|}
\hline WHAT & Moving images & Sounds (source) & On-screen text \\
\hline
\end{tabular}




\begin{tabular}{|c|c|c|c|}
\hline & $\begin{array}{l}\text { Relevant facts } \\
\text { (when, where and } \\
\text { who) and actions. } \\
\text { Physical } \\
\text { characteristics and } \\
\text { relationships of the } \\
\text { characters. }\end{array}$ & $\begin{array}{l}\text { Sound effects } \\
\text { difficult to } \\
\text { identify. } \\
\text { Lyrics of songs } \\
\text { and dialogues in } \\
\text { other languages }\end{array}$ & $\begin{array}{l}\text { Opening titles. } \\
\text { Casting. } \\
\text { Credits. } \\
\text { Any signs that } \\
\text { appear in the } \\
\text { screen as subtitles. }\end{array}$ \\
\hline WHEN & \multicolumn{3}{|c|}{ During gaps or silent moments between dialogues } \\
\hline HOW MUCH & \multicolumn{3}{|c|}{ Essential information for understanding the action } \\
\hline HOW & Style and register & Gram & structures \\
\hline
\end{tabular}

To sum up, $\mathrm{AD}$ requires the ability to summarise, as accurately as possible, the full sense of the original information based on an adequate understanding of the film's content and of the meaning of its visual aesthetics.

3.3 Film Literacy and AD in FL acquisition: A model

The concept of Film Literacy has a long tradition. The positive impact of 
film education has been recognised by many media studies researchers and teachers (Buckingham 2003; Ambròs and Breu 2007; Buckingham 2007; Burn and Durran 2007; British Film Institute 2008; Bazalgette 2009; British Film Institute 2010b). The principles of Film Literacy are summarised in the three "Cs": the critical, cultural and creative approaches to Film and Media Literacy (British Film Institute 2008; 2013). The critical approach focuses on recognising different types of stories. The cultural approach means broadening the range of films that the students have access to so that they can engage with a wider range of cultural perspectives; and, in the context of language teaching, we would like to add an intercultural /transcultural perspective that focuses on mediating between different cultures. Finally, the third approach brings creative filmmaking work to complement, support and expand learners' knowledge and understanding of what films can do.

Using a Cultural Studies framework gives learners a set of analytical tools for 'reading' the filmic text and rendering the cultural messages. The analysis of cinematography, mise-en-scène, editing, sound, genre conventions and narrative construction provides a solid ground to examine the way in which social, cultural, political and historical representations are conveyed in films, and how they are intertwined.

Recent reports and studies propose a model of Film Literacy education that includes critical reception and practice (BFI 2013). Therefore, one of the objectives of the AD task is to support learners in their development of film appreciation and creative practice. Ferrés and Piscitelli 
(2012) have proposed the dimensions and indicators to define Media Literacy that comprises Film Literacy. Their proposal focuses on two areas, the production of their own messages and the interaction with outside messages, and six major indicators: languages, technology, interaction processes, production and dissemination processes, ideology and values, and the aesthetic dimension. Based on Ferrés and Piscitelli's proposal $(2012,79-80)$, we propose in Table 3 a selection of the main competences, skills and knowledge required as part of Film Literacy training in AD. On the one hand, the skills in the area of analysis identify films as textual constructions, whose workings should be deconstructed by considering the different codes of representation (genre, cultural issues, aspects of industry, audience/s) and micro-components (mise-en-scène, sound, and so on). On the other hand, the model reiterates the importance of being able to be a creative producer of multimedia content.

Table 3. Main competences, skills and knowledge required as part of the film literacy training in AD, based on Ferrés and Piscitelli $(2012,79-80)$

\begin{tabular}{|l|l|l|}
\hline & $\begin{array}{l}\text { Skills in the area of } \\
\text { analysis }\end{array}$ & $\begin{array}{l}\text { Skills in the area of } \\
\text { expression }\end{array}$ \\
\hline Languages & $\begin{array}{l}\text { The ability to interpret } \\
\text { and evaluate the various } \\
\text { codes of representation } \\
\text { and the function they } \\
\text { perform within a message. }\end{array}$ & $\begin{array}{l}\text { Choose between different } \\
\text { systems of representation } \\
\text { and different styles } \\
\text { according to the } \\
\text { communication situation, } \\
\text { the type of content to be } \\
\text { transmitted and the type of } \\
\text { user. }\end{array}$ \\
\hline Technology & $\begin{array}{l}\text { The ability to handle } \\
\text { technological innovations } \\
\text { communication tools }\end{array}$ \\
\hline
\end{tabular}




\begin{tabular}{|c|c|c|}
\hline & $\begin{array}{l}\text { that make multimodal and } \\
\text { multimedia } \\
\text { communication possible. }\end{array}$ & $\begin{array}{l}\text { effectively in a multimedia } \\
\text { and multimodal } \\
\text { environment. }\end{array}$ \\
\hline $\begin{array}{l}\text { Interaction } \\
\text { processes }\end{array}$ & $\begin{array}{l}\text { Understand basic } \\
\text { concepts of audience, of } \\
\text { audience studies, their } \\
\text { usefulness and limitations. } \\
\text { Appreciate messages from } \\
\text { other cultures, for } \\
\text { intercultural dialogue in } \\
\text { an age of media without } \\
\text { borders. }\end{array}$ & $\begin{array}{l}\text { Demonstrate active } \\
\text { participation in the } \\
\text { interaction with screens, } \\
\text { understood as an } \\
\text { opportunity to construct a } \\
\text { more complete citizenry, } \\
\text { an integral development, } \\
\text { to be transformed, and to } \\
\text { transform the } \\
\text { environment. }\end{array}$ \\
\hline $\begin{array}{l}\text { Production and } \\
\text { dissemination } \\
\text { processes }\end{array}$ & $\begin{array}{l}\text { Recognize basic } \\
\text { conventions for } \\
\text { production systems, } \\
\text { programming techniques } \\
\text { and broadcasting } \\
\text { mechanisms. }\end{array}$ & $\begin{array}{l}\text { Select meaningful } \\
\text { messages, and use and } \\
\text { transform them to make } \\
\text { new meanings. }\end{array}$ \\
\hline $\begin{array}{l}\text { Ideology and } \\
\text { value }\end{array}$ & $\begin{array}{l}\text { Search for, organize, } \\
\text { contrast, prioritize and } \\
\text { synthesize information } \\
\text { from different systems and } \\
\text { environments. } \\
\text { Detect the intentions and } \\
\text { interests that underlie } \\
\text { corporate and popular } \\
\text { productions, their } \\
\text { ideology and values, latent } \\
\text { or patent, and take a } \\
\text { critical stance towards } \\
\text { them. }\end{array}$ & $\begin{array}{l}\text { Use new media and } \\
\text { communication tools to } \\
\text { transmit values and } \\
\text { contribute to improving } \\
\text { the environment based on } \\
\text { social and cultural } \\
\text { commitments. }\end{array}$ \\
\hline Aesthetics & $\begin{array}{l}\text { Enjoy formal aspects of } \\
\text { media, that is, not only of } \\
\text { what is communicated but } \\
\text { also how it is } \\
\text { communicated. } \\
\text { Identify basic aesthetic } \\
\text { categories like formal and } \\
\text { thematic innovation, } \\
\text { originality, style, schools } \\
\text { and trends. }\end{array}$ & $\begin{array}{l}\text { Produce elementary } \\
\text { messages that can be } \\
\text { understood and which } \\
\text { help to raise the level of } \\
\text { personal or collective } \\
\text { creativity, originality and } \\
\text { sensibility. } \\
\text { Appropriate and } \\
\text { transform artistic } \\
\text { productions, boosting } \\
\text { creativity, innovation, } \\
\text { experimentation and }\end{array}$ \\
\hline
\end{tabular}


The resultant model is based on two case studies carried out with undergraduate students at B2 level, according to the Common European Framework of Reference (CEFR) (Herrero 2014; Herrero and Escobar 2014) and numerous pedagogical interventions with secondary school students of Spanish as FL in the UK. ${ }^{\text {ix }}$ Based on Project-Based Learning, the training comprises of three main types of sessions. The first one is on visual rhetoric with an introduction to film language to guide students in carrying out a deeper investigation of the meaning of movies and developing their Film Literacy. It provides an introduction to macro analysis (ideology, representation, genre, cultural issues, narrative, aspects of the national film industry, etc.) and micro analysis (cinematography and mise-en-scène). The training guides leaners to draw plausible interpretations from relating the two levels of analysis. This session is complemented by an introduction to the multimodal approach, exploring how different modes are orchestrated to produce complex meaning. A second session focuses on auteurship providing an introduction to the filmmaking of Pedro Almodóvar. The workshop focuses on the style, themes and genres that have characterised Almodóvar's films since his first, subversive work in the 1980s. His films (Women on the Verge of a Nervous Breakdown, All about my Mother, Volver and Julieta) are relevant to the UK secondary school curriculum (1618 years-old). ${ }^{\mathrm{x}}$ Los abrazos rotos / Broken Embraces (2009) was chosen for 
the main case study for the following reasons. Firstly, it exemplifies the richness of Almodóvar's visual style, with complex meta-cinematic references, and a sophisticated narrative, all within a clear time structure. Secondly, it tells the story of a visually impaired filmmaker, bringing relevance to the AD training element. Furthermore, the Spanish and English DVDs provide AD in each language, respectively.

Finally, the third session comprises a short introduction to AD as well as relevant activities to support learners in the elaboration of the AD script. Pre-tasks include independent research on cultural aspects relevant to the film (gazpacho, the film Voyage to Italy, artist César Manrique, Lanzarote, and film noir), followed by film vocabulary and film analysis exercises. The main tasks were designed to practice how to audio describe and prepare the AD draft script. Scene or film clips were selected because of their relevance (description of characters and spaces), and because there were silent moments between dialogues The Study Guide "Audio description. Los abrazos rotos", which includes a summary of the sessions and activities is available to download from the FILTA Spanish resources area (www.filta.org.uk). ${ }^{\mathrm{xi}}$ Preliminary findings show a significant improvement of learners' Film Literacy and accessibility awareness. Students were more conscious of the need to be able to read the film language and understand the aesthetic style in order to produce an AD script.

Further evidence of the success of Film Literacy applied to language learning has been collected through professional training days, workshops, 
and film study days designed for pre-university students and language teachers and delivered since 2009 (i.e., enthusiasm, confidence and motivation; improved attitudes to writing; increased attainment in writing; improved linguistic skills; better understanding and application of concepts, and so forth). The effects noticed on teachers' attitudes and practices as well as students' results suggest there has been a change towards a more innovative way of conducting the FL class, especially promoting more frequent use of Film Literacy (Herrero 2016; FILTA).

In summary, the use of film in the FL classroom allows for the development and practice of audiovisual comprehension strategies in a holistic way, increasing the visual competence of the learners. Besides, it contributes to the development of film competence helping to perceive, analyse, and comprehend a number of communicative and cultural strategies (Chan and Herrero 2010; Thaler 2014; Herrero forthcoming). Language learners should be able to communicate in different media forms; therefore, it seems beneficial to introduce a practical component of audiovisual production (writing a screenplay for a short film, dubbing a film clip, or audio describing a short film without dialogues or a teaser) either as an individual task or as team work (Bahloul and Graham 2012; Keddie 2014; Donaghy 2015; Goldstein and Driver 2015; Video for all 2015; Anderson and Macleroy 2016; Herrero, forthcoming).

\section{Implications of the framework and conclusions}


$\mathrm{AD}$ is clearly a valuable tool with which to train students to develop their Visual Literacy, linguistic and cultural knowledge, even though research into its application to language teaching is in its infancy. In this article, we started by considering how research on AD tasks has concentrated mainly on linguistic and semantic content as well as the specific features of $\mathrm{AD}$ texts and their translatability. We laid out the conceptual base for $\mathrm{AD}$ pedagogy in FL within the multiliteracies framework, emphasising the importance of unifying the study of language and cultural content and working with multimodal texts, e.g. films that relate to learners' interests. The framework presented in this article provides the tools to support a productive engagement with film to improve FL learners' linguistic, cultural, intercultural and digital competences by elaborating an AD script within the principles of Project-Based Learning (PBL). In previous sections, we point out some of the competences developed through AVT tasks that are part of the employability skills associated with learning a language (see British Academy, 2016). AD requires a number of transferable competences and skills that may be useful for a wide range of professional sectors: linguistic competence; audiovisual and film competence; teamwork skills; cross competences (accessibility awareness); technological or applied competence; personal and general competences; and intercultural communicative competence.

The use of films in the FL classroom presents benefits and challenges for learners and teachers. In order to generate the AD script, 
learners have to acquire the relevant film terminology and Visual Literacy as well as pay attention to paralinguistic elements that will help to render a comprehensive linguistic, social, cultural, and intercultural description. For a productive engagement with this type of project, Film Literacy should be included as part of the language curriculum (Chan and Herrero 2010; Lardoux 2014; Herrero 2016). Understanding the basic components of film studies is essential to appreciate cinema as an aesthetic medium and how it generates meaning and responses. Such training is essential for students to audio describe a film (or part of a film) adequately. The use of the framework, which has been tested on Higher Education language students, incorporates a more comprehensive approach to bringing Film Literacy via critical, cultural, intercultural and creative approaches - into the FL classroom. It responds to the need to engage language learners in crosscurricular tasks and approaches.

In conclusion, $\mathrm{AD}$ creative projects constitute a useful and practical way of offering a FL project-based tasks. The activities engage students in the process of critically 'reading' films, creating a text that makes connections and translating images into words. When selecting the appropriate text for students, it is important to consider the background knowledge needed, as well as how the text directs learners' attention to the multimodal orchestration. Ultimately, the AD project incorporates a holistic approach that includes translation skills, critical, cultural and intercultural competences, and supports the development of Film Literacy. 


\section{References}

AENOR. 2005. UNE 153020. Audiodescripción para personas con discapacidad visual. Requisitos para la audiodescripción y elaboración de audioguías. Madrid: AENOR.

Altman, Rick. 1989. The Video Connection: Integrating Video into Language Teaching. Boston, MA: Houghton, Mifflin Company.

Ambròs, Alba, and Ramón Breu. 2007. Cine y educación: El cine en el aula de primaria y secundaria. Barcelona: Graó.

Anderson, Jim, and Vicky Macleroy. 2016. Multilingual Digital Storytelling. London and New York: Routledge.

Argüelles Díaz, Alba. 2015. Los anuncios en la clase de ELE: una propuesta didáctica. Oviedo: Universidad de Oviedo. http://hdl.handle.net/10651/33779

Baddock, Barry. 1996. Using Films in the English Class. Hertfordshire: Phoenix ELT.

Bahloul, Maher, and Carolyn Graham, eds. 2012. Lights! Camera! Action and the Brain: The Use of Film in Education. Newcastle upon Tyne: Cambridge Scholars.

Baños, Rocío, and Stavroula Sokoli. 2015. "Learning foreign languages with ClipFlair: Using captioning and revoicing activities to increase students' motivation and engagement." In 10 Years of the LLAS Elearning Symposium: Case Studies in Good Practice ed by Kate 
Borthwick, Erika Corradini and Alison Dickens, 203-213.. Dublin and Voillans: Research-publishing.net.

Barrett, Martin, Michael Byram, Ildikó Lázár, Pascale Mompoint-Gaillard, and Stavroula Philippou. 2014. Developing Intercultural Competence through Education. Strasbourg: Council of Europe Publishing.

Bazalgette, Cary. 2009. Impacts of Moving Image Education: a summary of research. Glasgow: Scottish Screen.

Bird, Stephen A., and John N. Williams. 2002. "The effect of bimodal input on implicit and explicit memory: An investigation into the benefits of within-language subtitling." Applied Psycholinguistics 23 (4): 509533.

Borghetti, Claudia. 2011. "Intercultural learning through subtitling: The cultural studies approach.” In Audiovisual translation: subtitles and subtitling: theory andpractice, ed. by Laura Incalcaterra McLoughlin, Marie Biscio, and Máire Aine. Ní Mhainnín, 111-138. Bern: Peter Lang.

Borrás, Isabel, and Robert C. Laffayete. 1994. "Effects of multimedia course subtitling on the speaking performance of college students in French.” The Modern Language Journal 78 (1): 61-75.

Bourne, Julián, and Catalina Jiménez Hurtado. 2007. "From the visual to the verbal in two languages: a contrastive analysis of the audio description of The Hours in English and Spanish." In Media for all: Subtitling for the deaf, audio description and sign language, ed. by 
Pilar Orero, and Aline Remael, 175-187. Amsterdam: Editions Rodopi.

Brandimonte, Giovanni. 2003.“El soporte audiovisual en la clase de E/LE: el cine y la televisión.” In Medios de comunicación y enseñanza del español como lengua extranjera. Actas del XIV congreso de ASELE, ed. by Hermógenes Perdiguero, and Antonio Álvarez, 870-881. Burgos: Servicio de Publicaciones Universidad de Burgos.

Bravo, Conceição. 2008. Putting the Reader in the Picture: Screen Translation and Foreign-Language Learning. PhD Diss Tarragona: University Rovira i Virgili.

British Academy. 2016. Born Global. Accessed March 5, 2016. http://www.britac.ac.uk/born-global

British Film Institute. 2008. Reframing Literacy, BFI, London, BFI. Accessed March 5, $2016 . \quad$ http://www.bfi.org.uk/screeningliteracy-film-education-europe

British Film Institute 2010a. Making the case for film education (21st Century Literacies). London: British Film Institute.

British Film Institute. 2010b. Film: 21st Century Literacy -Pilot Project Blueprints. London: British Film Institute.

British Film Institute. 2013. Screening Literacy in Europe. London: British Film Institute.

Buckingham, David. 2003. Media Education: Literacy. Learning and Contemporary Culture. Cambridge: Polity Press. 
Buckingham, David. 2007. Beyond technology: Children's Learning in the Age of Digital Dulture. Cambridge: Polity.

Burn, Andrew, and James Durran. 2007. Media literacy in schools: Practice, production and progression. London: Sage.

Burn, Andrew. 2013. The kineikonic mode: Towards a Multimodal Approach to Moving Iimage Media. Accessed March 5, 2016. http://eprints.ncrm.ac.uk/3085/1/KINEIKONIC_MODE.pdf

Bustos Gisbert, José Manuel. 1997. “Aplicaciones del vídeo a la enseñanza de español como lengua extranjera." Carabela 42: 93-105.

Byram, Michael, Prue Holmes, and Nicola Savvides. 2013. "Intercultural communicative competence in foreign language education: Questions of theory, practice and research.” The Language Learning Journal 41 (3): 251-253.

Caimi, Annamaria. 2006. “Audiovisual translation and language learning: The promotion of intralingual subtitles." The Journal of Specialised Translation 6: 85-98.

Canale, Michael, and Merrill Swain. 1980. "Theoretical bases of communicativeapproaches to second language teaching and testing." Applied linguistics 1 (1): 1-47.

Canale, Michael. 1983. "From communicative competence to communicative language pedagogy." Language and communication 1: $1-47$.

Canning-Wilson, Christine. 2000. "Practical Aspects of Using Video in the 
Foreign Language Classroom.” The Internet TESL Journal 6 (11). Accessed March 5, 2016.http://iteslj.org/Articles/Canning-Video.html Cardillo, Darlene S. 1996. "Using a foreign film to improve second language proficiency: Video vs. interactive multimedia." Journal of Educational Technology Systems 25 (2): 169-177.

Celce-Murcia, Marianne. 1995. "The elaboration of sociolinguistic competence: Implications for teacher education". In Linguistics and the Education of Language Teachers: Ethnolinguistic, Psycholinguistic, and Sociolinguistic Aspects. Proceedings of the Georgetown University, Round Table on Languages and Linguistics, ed. by James E. Alatis, Carolyn A. Straehle, and Maggie Ronkin, 699710. Georgetown University Press, Washington DC.

Celce-Murcia, Marianne, Zoltan Dörnyei, and Sarah Thurrell. 1995. “Communicative competence: A pedagogically motivated model with content specifications." Issues in Applied linguistics 6 (2): 5-35.

Chan, Deborah, and Carmen Herrero. 2010. Using Film to Teach Languages. Manchester: Cornerhouse. https://goo.gl/mosW5h

Chapple, Lynda, and Andy Curtis. 2000. "Content-based instruction in Hong Kong: $\quad$ Student responses to film.” System 28 (3): 419-433. Chiu, Yi-hui. 2012. "Can film dubbing projects facilitate EFL learners' acquisition of English pronunciation?" British Journal of Educational Technology 43 (1): 24-27.

Chung, Jing Mei, and S. C. Huang. 1998. "The effects of three aural 
advance organizers for video viewing in a foreign language classroom.” System 26 (4): 553-565.

Clark, Joe. 2007. "Standard techniques in audio description". Joe Clark (Accessibility, Design, Writing) Accessed March 5, 2016. https://joeclark.org/access/description/ad-principles.html

Condliffe, Barbara, Mary G. Visher, Michael R. Bangser, J.D. Sonia Drohojowska, and Larissa Saco. 2016. Project-Based Learning: A Literature Review. New York, NY: MDRC. Accessed March 5, 2016. https://s3-us-west-

1.amazonaws.com/ler/MDRC+PBL+Literature+Review.pdf

Cope, Bill, and, Mary Kalantzis, eds. 2000. Multiliteracies: Literacy Learning and the Design of Social Futures. London: Routledge.

Cope, Bill, and Mary Kalantzis. 2009. “Multiliteracies': New literacies, new learning." $\quad$ Pedagogies: An international journal 4 (3): 164-195.

Corpas Viñals, Jaime. 2000. “La utilización del vídeo en el aula de E/LE. El componente cultural." In Actas del XI Congreso Internacional de ASELE, ed. by María Antonia Martín Zorraquino, and Cristina Díez Pelegrín, 785-791. Zaragoza: Universidad de Zaragoza.

Council of Europe. 2001. Common European Framework of Reference for Languages: Learning, Teaching, Assessment. Cambridge: Cambridge University Press. 
Crespo Fernández, Ana. 2012. Explotación didáctica de material filmico en el aula de E/LE: efectividad y afectividad del cine de Pedro Almodóvar. PhD Diss. Córdoba: Universidad de Córdoba.

Danan, Martine. 2004. "Captioning and subtitling: Undervalued language learning strategies." Meta: Journal des traducteurs. Meta: Translators' Journal 49 (1): 67-77.

Dervin, Fred, and Anthony Liddicoat, eds. 2013. Linguistics for Intercultural Education. Amsterdam and Philadelphia: John Benjamins Publishing.

Díaz-Cintas, Jorge. 2006. Competencias profesionales del subtitulador y el audiodescriptor. Madrid: CESyA. Accessed March 5, 2016.

http://www.cesya.es/estaticas/jornada/documentos/informe.pdf

Díaz-Cintas, Jorge. 2010. "La accesibilidad a los medios de comunicación audiovisual a través del subtitulado y de la audiodescripción.” In $E l$ español, lengua de traducción para la cooperación y el diálogo, ed. by Luis González, and Pollux Hernúñez, 157-180. Madrid: Instituto Cervantes.

Díaz-Cintas, Jorge. 2012. "Los subtítulos y la subtitulación en la clase de lengua extranjera." Abehache, Revista da Associação Brasileira de Hispanistas 2 (3): 95-114.

Díaz-Cintas, Jorge, Pilar Orero, and Aline Remael. 2007. "Media for all: a global challenge." In Media for All: Subtitling for the Deaf, Audio 
Description, and Sign Language, ed. by Pilar Orero, and Aline Remael, 11-20. Amsterdam, New York: Rodopi.

Donaghy, Kieran. 2015. Film in Action: Teaching Language Using Moving Images. Surrey: Delta Publishing.

Ferrés, Joan, and Alejandro Piscitelli. 2012. "Media Competence. Articulated Proposal of dimensions and indicators." Comunicar 19 (38): 75-81.

Film in Language Teaching Association (FILTA). Accessed 14 Feburary 2017. www.filta.org.uk

Gambier, Yves. 2007. "Sous-titrage et apprentissage des langues." Linguística Antverpiensia 6: 97-113.

Gilmore, Alex. 2007. "Authentic materials and authenticity in foreign language learning." Language Teaching 40: 97-118.

Goldstein, Ben, and Paul Driver. 2015. Language Learning with Digital Video. Cambridge: Cambridge University Press.

Greening, Joan, and Deborah Rolph. 2007. “Accessibility: raising awareness of audio description in the UK." In Media for all: Subtitling for the deaf, audio description and sign language, ed. by Pilar Orero, and Aline Remael, 127-138. Amsterdam: Editions Rodopi.

Guerra Robles, Patricia. 2013. El corto en el aula de ELE y la enseñanza del léxico en contexto. M.A. diss. Oviedo: Universidad de Oviedo. 
Guillory, Helen Gant. 1998. "The effects of keyword captions to authentic French video on learner comprehension." Calico Journal 15 (1): 89108.

Herrero, Carmen. 2009. "El uso de cortometrajes en la clase de español: la representación de las minorías étnicas.” Jornadas Didácticas Del Instituto Cervantes Manchester, Biblioteca virtual redELE. Accesed May, 10, 2016. $\quad$ http://www.mecd.gob.es/redele/BibliotecaVirtual/2009/Numeros-

Especiales/I_JORNADAS_INSTITUTO_CERVANTES_MANCHES TER.html

Herrero, Carmen. 2014. “Crossing boundaries: Developing Intercultural Competence Through Film”. Paper presented at the Symposium Raising Intercultural Awareness, Manchester: Manchester Metropolitan University, 12 June.

Herrero, Carmen. 2016. "The Film in Language Teaching Association (FILTA): a multilingual community of practice." ELT Journal 70 (2): 190-199.

Herrero, Carmen. Forthcoming. "El cine y otras manifestaciones culturales en ELE.” In Iniciación a la metodología de la enseñanza de ELE. Diseño curricular (vol. IV), ed. by María Martínez-Atienza de Dios and Alfonso Zamorano Aguilar. Madrid: EnClave-ELE.

Herrero, Carmen, and Manuela Escobar. 2014. "Un modelo integrador de cine y audio descripción para el aprendizaje de lenguas extranjeras: 
Los abrazos rotos (Almodóvar)." Paper presented at the ClipFlair conference. Innovation in Language Learning: Multimodal Approaches. Barcelona: Universitat Autònoma de Barcelona, 18-20 June.

Herron, Carol. 1994. "An investigation of the effectiveness of using an advance organizer to introduce video in the foreign language classroom.” The Modern Language Journal 78 (2): 190-198.

Herron, Carol, Julia E. Hanley, and Steven. P. Cole. 1995. “A comparison study of two advance organizers for introducing beginning foreign language students to video." The Modern Language Journal 79 (3): 387-395.

Holmes, Len. 1995. "Skills: a social perspective.” In Transferable Skills in Higher Education, ed. by Alison Assister, 20-28. London: Kogan Page.

Ibáñez Moreno, A. y A. Vermeulen. 2014. "La audiodescripción como recurso didáctico en el aula de ELE para promover el desarrollo integrado de competencias". In New Directions in Hispanic Linguistics, ed. by Rafael Orozco, 264-292. Newcastle upon Tyne: Cambridge Scholars Publishing.

Incalcaterra McLoughlin, Laura, and Jennifer Lertola. 2011. "Learn through subtitling: Subtitling as an aid to language learning." In Audiovisual Translation Subtitles and Subtitling. Theory and Practice, eds. 
Laura Incalcaterra McLoughlin, Marie Biscio, and Máire Aine Ní Mhainnín, 243-263. Bern: Peter Lang.

Incalcaterra McLoughlin, Laura, and Jennifer Lertola. 2014. “Audiovisual translation in second language acquisition. Integrating subtitling in the foreign-language curriculum." The Interpreter and Translator Trainer 8 (1): 70-83.

Jenkins, Henry. 2008. Convergence culture: La Cultura de la Convergencia de los Medios. Barcelona: Paidós.

Jenkins, Henry, et al. 2009. Confronting the Challenges of Participatory Culture: Media Education for the $21^{\text {st }}$ Century. Cambridge, MA: MIT Press.

Jones, Elspeth. 2013. "Internationalization and employability: the role of intercultural experiences in the development of transferable skills." Public Money and Management 33 (2): 95-104.

Keddie, Jamie. 2014. Bringing Online Video into the Classroom. Oxford: Oxford University Press.

Kern, Richard. 2003. "Literacy as a new organizing principle for foreign language education. In Reading between the lines: perspectives on foreign language literacy, ed. by Peter C. Patrikis, 40-59. New Haven, CT: Yale University Press.

Kress, Günther, and Theo van Leeuwen. 2001. Multimodal Discourses: The Modes and Media of Contemporary Communication. New York: Oxford University Press. 
Kress, Günther. 2003. Literacy in the New Media Age. London: Routledge.

Kress, Günther. 2010. Multimodality. London: Routledge

Lankshear, Colin, and Michele Knobel. 2003. New Literacies: Changing Knowledge and Classroom Learning. Buckingham: Open University Press.

Lardoux, Xavier. 2014. For a European Film Education Policy. Paris: Centre national du cinéma et de l'image animée. Accessed May 15, 2015.

http://www.europacreativamedia.cat/rcs_media/For_a_European_Film _Education_Policy.pdf

Leu, Donald J, Charles K. Kinzer, Julie Coiro, Jill Castek, and Laure A. Henry. 2013. "New literacies: A dual level theory of the changing nature of literacy, instruction, and assessment." In Theoretical models and processes of reading, ed. by Donna E. Alvermann, Norman J. Unrau and Robert B. Ruddell, (6th ed.), 1150-1181. Newark, DE: International Reading Association.

Lin, Huifen and Tsuiping Chen. 2006. "Decreasing cognitive load for novice EFL learners: Effects of question and descriptive advance organizers in facilitating EFL learners' comprehension of an animation-based content lesson.” System 34 (3): 416-431. http://dx.doi.org/10.1016/j.system.2006.04.008. 
Maszerowska, Anna, Anna Matamala, and Pilar Orero, eds. 2014. Audio Description. New Perspectives Illustrated. John Benjamins: Philadelfia and Amstedam.

Matamala, Anna. 2006. "La accesibilidad en los medios: aspectos lingüísticos y retos de formación." In Sociedad, Integración y Televisión en España, ed. by Ricardo Amat, and Álvaro Pérez-Ugena, 293-306. Madrid: Laberinto.

Matamala, Anna y Pilar Orero. 2007. "Designing a Course on Audio Description and Defining the Main Competences of Future Professional." Linguistica ～Antverpiensia 6: 329-344. http://www.lans-tts.be/img/NS6/LANS6 MO.pdf

Matamala, Anna, and Pilar Orero, eds. 2016. Researching AudioDescription. New Approaches. Basingstoke: Palgrave Macmillan.

Meler, Mirna. 2005. "El anuncio publicitario televisivo en la enseñanza E/LE: una aproximación a los componentes socioculturales." Cuadernos Canela 17: 89-108.

Navarrete, Marga. 2013. "El doblaje como herramienta de aprendizaje en el aula de español y desde el entorno de CLIPFLAIR". MarcoELE 16: $75-87$.

New London Group. 1996. “A pedagogy of multiliteracies: Designing social futures." Harvard Educational Review 66 (1): 60-92.

Nunan, David. 1989. Designing Tasks for the Communicative Classroom. Cambridge: Cambridge University Press. 
Ofcom. 2015. "Code on Television Access Services.” Accessed January 2017. https://www.ofcom.org.uk/_data/assets/pdf_file/0020/97040/Accessservice-code-Jan-2017.pdf

Openlearn. 2010. "Language and literacy in a changing world." Accessed May 10, 2016.

http://www.open.edu/openlearnworks/mod/oucontent/view.php?id=15 196andsection $=4.1$

Orero, Pilar. 2007. "Sampling audio description in Europe." In Media for all: Subtitling for the deaf, audio description and sign language, ed. by Pilar Orero, and Aline Remael, 111-125. Amsterdam: Rodopi.

Orero, Pilar and Anna Matamala. 2007. “Accessible Opera: Overcoming Linguistic and Sensorial Barriers." Perspectives Studies in Translatology 15 (4): 262-267.

Orero, Pilar. 2012. "Film Reading for Writing Audio Descriptions: A Word is worth a Thousand Images?" In Emerging Topics in Translation: Audio Description, ed. by Elisa Perego, 13-28. Trieste: Edizioni Università di Trieste.

Paesani, Kate, Heather W. Allen, and Beatrice Dupuy. 2016. A Multiliteracies Framework for Collegiate Foreign Language Teaching. Upper Saddle River, NJ: Pearson. 
Pegrum, Mark. 2008. "Film Culture and Identity: Critical Intercultural Literacies for the Language Classroom." Language and International Communication 8 (2): 136-154.

Pérez Basanta, Carmen. 1999. "El uso del video en la enseñanza de una lengua extranjera: Beauty and the Beast. Una actividad para la comprensión oral, la adquisición léxica y la reflexión sobre la estructura del lenguaje narrativo." In Actas de las VII Jornadas Internacionales sobre la Enseñanza de Lenguas, ed. by Ángla Celis and José Ramón Heredia, 369-378. Granada: Servicio de Publicaciones de la Universidad de Granada.

Porcel, Carme. 2009. "Using films in class." Modern English Teacher 18 (3): 24-29.

Rai, Sonali, Joan Greening, and Leen Petré. 2010. A comparative study of audio description guidelines prevalent in different countries. London: RNIB.

Romero-Fresco, Pablo. 2013. "Accessible filmmaking: Joining the dots between audiovisual translation, accessibility and filmmaking." The Journal of Specialised Translation 20: 201-223.

Ruiz Fajardo, Guadalupe. 1994. "Video en clase. Virtudes y vicios". MarcoELE 8: 141-164.

Sánchez-Requena, Alicia. 2016. "Audiovisual Translation in Teaching Foreign Languages: Contributions of Revoicing to Improve 
Portalinguarum 26: 9-21

Sherman, Jane. 2003. Using Authentic Video in the Language Classroom. Cambridge: Cambridge University Press.

Snyder, Joel. 2013. Audio Description: Seeing With the Mind's EyeA Comprehensive Training Manual and Guide to the History and Applications of Audio Description. PhD Diss. Barcelona: Universitat Autonoma de Barcelona.

Sokoli, Stavroula. 2006. "Learning via subtitling (LvS). A tool for the creation of foreign language learning activities based on film subtitling." In EU-High-Level Scientific Conference Series MuTra 2006: Audiovisual Translation Scenarios: Conference Proceedings, 15. http://www.euroconferences.info/proceedings/2006_Proceedings/20 06_Sokoli_S travoula.pdf

Sokoli, Stavroula, Patrick Zabalbeascoa, and Maria Fountana. 2011. "Subtitling Activities for Foreign Language Learning: What Learners and Teachers Think.” In Audiovisual Translation Subtitles and Subtitling. Theory and Practice, ed. by Laura Incalcaterra McLoughlin, Marie Biscio, and Máire Aine, Ní Mhainnín, 219-242. Bern: Peter Lang.

Talaván, Noa. 2010. "Subtitling as a Task and Subtitles as Support: Pedagogical Applications." In New Insights into Audiovisual 
Translation and Media Accessibility, ed. by Jorge Díaz-Cintas, Anna Matamala, and Joselia Neves, 285-299. Amsterdam: Rodopi.

Talaván, Noa. 2013. La subtitulación en el aprendizaje de lenguas extranjeras. Barcelona: Octaedro.

Talaván, Noa, and José Javier Ávila-Cabrera. 2015. "First insights into the combination of dubbing and subtitling as L2 didactic tools." In Subtitles and Language Learning, ed. by Yves Gambier, Annamaria Caimi, and Cristina Mariotti, 149-172. New York: Peter Lang.

Talaván, Noa, Jose Javier Ávila-Cabrera, and Tomás Costal. 2016. Traducción y accesibilidad audiovisual. Barcelona: Editorial UOC.

Talaván, Noa, and Jennifer Lertola. 2016. “Active Audiodescription to Promote Speaking Skills in Online Environments.” Sintagma, Revista de Lingüística 28: 59-74.

Thaler, Engelbert. 2014. Teaching English with Films. Paderborn: Schöningh.

Thomas, John W. 2000. "A Review of Research on Project-Based Learning.” Accessed June 15, 2015. http://www.newtechnetwork.org.590elmp01.blackmesh.com/sites/defa ult/files/dr/pblresearch2.pdf

Toro Escudero, Juan Ignacio. 2009. "Enseñanza del español a través del cine hispano: Marco teórico y ejemplos prácticos." MarcoELE 8. $\begin{array}{llll}\text { Accessed June } & \text { 6, }\end{array}$ http://www.marcoele.com/descargas/china/ji.toro_cinehispano.pdf 
Wilson, Carolyn, Alton, Grizzle, Alton, Ramon, Tuazon, Kwame, Akyempong, and Chi-Kim, Cheung, 2011.Media and Information Literacy Curriculum for Teachers. Paris: UNESCO. http://unesdoc.unesco.org/images/0022/002256/225606e.pdf

Vanderplank, Robert. 1988. "The value of teletext sub-titles in language learning.” ELT Journal 42 (4): 272-281.

Vanderplank, Robert. 2010. "Déjà vu? A Decade of Research on Language Laboratories, Television and Video in Language Learning." Language Teaching 43 (1): 1-37.

Vercauteren, Gert. 2007. "Towards a European Guideline for Audio Description." In Media for all: Subtitling for the deaf, audio description and sign language, ed. by Jorge Díaz-Cintas, Pilar Orero, and Aline Remael, 139-149. Amsterdam: Rodopi.

Video for all. Accessed 24 May 2016. http://videoforall.eu

Vílchez Tallón, José Antonio. 2007. La enseñanza del componente pragmático a través de fragmentos de películas. Madrid: Universidad de Alcalá.

Webb, Stuart, and Michael P. Rodgers. 2009. "The Lexical Coverage of Movies.” Applied Linguistics 30 (3): 407-427.

Weyers, Joseph R. 1999. "The Effect of Authentic Video on Communicative Competence." The Modern Language Journal 83 (3): 339-349. 
Williams, Helen, and David Thorne. 2000. "The Value of Teletext

Subtitling as a Medium for Language Learning.” System 28 (2): 217-

228.

\footnotetext{
${ }^{\mathrm{i}}$ Film Literacy has more recently been defined as "the level of understanding of a film, the ability to be conscious and curious in the choice of films; the competence to critically watch a film and to analyse its content, cinematography and technical aspects; and the ability to manipulate its language and technical resources in creative moving image production.” (British Film Institute 2013, 8).

ii Nunan $(1989,10)$ defined task as a "piece of classroom work which involves learners in comprehending, manipulating, producing or interacting in the target language, while their attention is principally focused on meaning rather than form."

iii The New London Group refers to the ten leaders in the field of literacy pedagogy who met in 1999 in the small town of New London, New Hampshire, in order to discuss the growing importance of cultural and linguistic diversity and multimodal literacy due to the power of new communication technologies. The outcome of their discussions was encapsulated under the term 'Multiliteracies'.
}

${ }^{\text {iv }}$ Authentic texts for language teaching relates to two of the meanings considered by Gilmore $(2007,97-8)$ in his literature review: a) those that contain "language produced by a real speaker/writer for a real audience, conveying a real"; b) those that "relate to culture, and the ability to behave or think like a target language group in order to be recognized and validated by them". Media for all: Subtitling for the deaf, audio description and sign language,

${ }^{v}$ www.clipflair.net (accessed August 7, 2017).

${ }^{\text {vi }}$ Of special interest is the project http://www.adlabproject.eu (accessed August 7, 2017).

vii Borghetti (2011) distinguishes two phases in the viewing of films in FL AVT contexts; first, foreign language students attempt to decode the film according to their own schemata, and later they become translators (encoding process) for the target audience. The same principles can be applied to AD, adding a filmic and multimodal analysis.

viii See Díaz-Cintas (2006) for the essential and desirable professional competences for audio describers, some of them very relevant to the employability skills required of language learners in the $21^{\text {st }}$ century.

ix The Common European Framework of Reference for Languages "provides a common basis for the elaboration of language syllabuses, curriculum guidelines, examinations, textbooks, etc. across Europe" (Council of Europe 2001, 1). The CEFR defines six proficiency levels: Basic User (A1-A2), Independent User (B1-B2) and Proficient User (C1-C2). The CEFR specifies which competencies, knowledge and skills learners are 
expected to reach at each level.

${ }^{x}$ Depending on the examination board responsible for setting and awarding secondary education level qualifications in the United Kingdom, students must study either one literary text and one film or two films from a list provided drawing on advice from subject experts from Higher Education establishments and subject associations. Almodóvar's films are included in the list of prescribed works of all of the awarding bodies.

${ }^{x i}$ http://filtacommunity.ning.com/page/spanish-study-guides (accessed August, 7 2017). 